\title{
Edukasi Tanggap Bencana Pada Masyarakat Di Desa Slahung Kabupaten Ponorogo
}

\author{
Aris Heri Andriawan ${ }^{1 *}$, Eko April Ariyanto 2 , M. Faiz Imron ${ }^{3}$, Achmad Rizal Syafi'i ${ }^{4}$ \\ ${ }^{1}$ Fakultas Teknik, Program Studi Teknik Elektro, Universitas 17 Agustus 1945 Surabaya, ${ }^{2}$ Fakultas \\ Psikologi, Program Studi Psikologi, Universitas 17 Agustus 1945 Surabaya, ${ }^{3}$ Fakultas Teknik, Program \\ Studi Teknik Elektro, Universitas 17 Agustus 1945 Surabaya, ${ }^{4}$ Fakultas Psikologi, Program Studi \\ Psikologi, Universitas 17 Agustus 1945 Surabaya \\ * Penulis Korespondensi: E-mail: aris_po@untag-sby.ac.id
}

\begin{abstract}
Slahung village is one of the villages in Ponorogo Regency whose area is more than $66.65 \%$ in the form of hills/ mountains with a slope between 30-85 degrees. With these geographical conditions, the area is categorized as a village prone to landslides. The last landslide occurred in February - March 2018, resulting in one heavy house and 20 houses being lightly damaged and 141 residents having to evacuate. The threat of landslides is now greater as land use is not optimal. People's forests are transformed into farmland that makes use of the slopes. In addition, the ground level drainage system is not good so that all rainwater and household waste is not absorbed optimally. This condition is exacerbated by poor settlement arrangements. Community residents do not consider the slope of land, cracks, or waterways when building houses. They are only oriented towards residential development by utilizing existing land. The purpose of this program is to provide knowledge to the community about the potential disasters that can occur, efforts that must be made to avoid the fall of many fatalities and property as well as the introduction of evacuation routes as well as to practice evacuation in the event of a disaster.
\end{abstract}

Keywords: Disaster Response Education, Disaster Potential, Community

\begin{abstract}
Abstrak
Desa Slahung merupakan salah satu desa di Kabupaten Ponorogo yang wilayahnya lebih dari $66,65 \%$ berupa perbukitan/pegunungan dengan kemiringan antara 30-85 derajat. Dengan kondisi geografi tersebut, wilayah ini dikategorikan sebagai desa yang rawan terhadap bencana longsor. Bencana longsor terakhir kali terjadi pada bulan februari - maret 2018 yang mengakibatkan satu rumah rusah berat dan 20 rumah rusak ringan serta 141 penduduk harus mengungsi. Ancaman bencana longsor saat ini semakin besar terjadi seiring pemanfaatan lahan yang tidak optimal. Hutan-hutan rakyat berubah menjadi lahan pertanian yang memanfaatkan lereng-lereng. Selain itu sistem drainase permukaan tanah yang kurang baik sehingga seluruh air hujan maupun limbah rumah tangga tidak terserap optimal. Kondisi ini diperparah dengan penataan pemukiman yang buruk. Warga masyarakat tidak mempertimbangkan kemiringan lahan, retakan, maupun jalur aliran air ketika membangun rumah. Mereka hanya berorientasi pada pembangunan tempat tinggal dengan memanfaatkan lahan yang ada. Tujuan dari program ini adalah memberikan pengetahuan kepada masyarakat tentang potensi bencana yang bisa terjadi, upaya yang harus dilakukan untuk menghindari jatuhnya banyak korban jiwa maupun harta benda serta pengenalan jalur evakuasi sekaligus melakukan praktek evakuasi apabila sewaktu-waktu bencana akan terjadi.
\end{abstract}

Kata kunci: Edukasi Tanggap Bencana, Potensi Bencana, Masyarakat

\section{PENDAHULUAN}

Desa Slahung adalah desa yang letaknya berdampingan dengan desa Snepo dan termasuk bagian dari 22 desa di Kecamatan Slahung-Kabupaten Ponorogo. Jarak kantor Desa 
Slahung dan Desa Senepo ke ibukota kecamatan sejauh $\pm 12 \mathrm{~km}$ dan ke ibukota kabupaten sejauh $\pm 34 \mathrm{~km}$. Sesuai dengan namanya "Slahung" berasal dari bahasa jawa "slah gunung", artinya berada di sela-sela gunung. Topografi kedua desa tersebut $>66,65 \%$ nya berupa perbukitan / pegunungan dengan kemiringan antara $30^{\circ} \mathrm{s} / \mathrm{d} 85^{\circ}$. Dari survei yang dilakukan, keduanya terletak di ketinggian $755 \mathrm{mdpl} \mathrm{s} / \mathrm{d} 900 \mathrm{mdpl}$, secara administrasi desa Slahung terbagi menjadi 5 (lima) dusun yaitu dusun Dawang, dusun Jaten, dusun Tengger, dusun Bandungan dan dusun Gembes, sedangkan desa Senepo terdiri dari 4 (empat) dusun yaitu dusun Krajan, dusun Kowang, dusun Genuk dan dusun Salak.

Kondisi hidrologi seperti kondisi air tanah tidak mengandung kadar garam yang tinggi sehingga memberi kemudahan pemilihan tanaman tropis yang variatif. Kondisi iklim, rata-rata curah hujannya mencapai $2000 \mathrm{~mm}$ pertahun, suhu berkisar antara $28^{\circ} \mathrm{C}-30^{\circ} \mathrm{C}$ dengan iklim tropis. Hampir setiap tahun saat musim hujan tiba, bencana tanah longsor terus menghantui penduduk kedua desa tersebut. Tanah longsor terakhir terjadi bulan Pebruari-Maret 2018, satu rumah rusak berat, 20 rumah terancam longsoran tanah dan sedikitnya 141 jiwa harus mengungsi serta terputusnya akses jalan yang menghubungkan dengan dukuh dan desa lain. Belum lagi longsoran-longsoran kecil yang sering terjadi saat musim hujan disemua dusun.

Dari survei yang dilakukan nampaknya bencana akan semakin mengancam karena adanya perubahan penggunaan lahan yang semula berupa hutan rakyat berubah menjadi lahan pertanian. Pemanfaatan lahan sebagai lahan pertanian memanfaatkan lereng yang relatif curam, sehingga erosi akan sering terjadi dalam bentuk erosi alur dan gerakan massa tanah (retakan) disamping itu sistem drainase permukaan yang kurang baik sehingga seluruh air baik air hujan maupun air limbah rumah tangga menjenuhi lereng sehingga mempercepat berkembangnya longsor. Jenis gerakan yang tanah terjadi di dusun Gembes tergolong gerakan tanah tipe kompleks, terdapat jenis longsoran pada bagian atas bukit, kemudian pada bagian tengah dan atas karena efek dorongan dan tarikan muncul retakan-retakan atau dengan arah gerakan tanah 35-45 (relatif timur laut). Pada lereng bagian atas kemiringan lereng, $>35^{\circ}$, retakan memanjang sepanjang $170 \mathrm{~m}$ dan tanah turun bervariasi dari 40-125 cm, terdapat longsoran dengan lebar mahkota 20 E (timur laut), tepat di bawahnya Lingkungan Duren. Longsoran dimensi kecil dan retakan juga mengancam 4 rumah di Kp. Lingkungan Salam, dengan panjang retakan berkisar 30 meter. Gejala longsoran dan tarikan berupa retakan akibat dorongan dari atas juga terjadi di Kp. Duren. Longsoran di Kp. Duren dengan panjang mencapai 160 meter, lebar mahkota 34 meter, muncul retakan-retakan pada halaman maupun ladang dengan lebar 5-20 cm panjang mencapai 50-100 meter. Pada bagian atas di Dusun Genuk yang berbatasan dengan lingkungan Salam, Dusun Senepo terjadi retakan dengan panjang 10-23 meter dan lebar retakan berkisar 5-10 cm. Di bagian bawah terdapat longsoran yang mengarah ke lembah atau alur sungai kecil. Longsoran sangat tipis karena tanah pelapukan tipis dan didominasi batuan kecil. Dengan arah longsoran barat laut. Longsoran ini yang dikhawatirkan mengancam Lingkungan Klandiri. Sementara bagian bawah lingkungan Klandiri terjadi longsoran lambat yang menyebabkan 2 rumah retak atau keramaik rusak, hal ini akibat tarikan dari longsoran yang terjadi di sungai.

Secara umum factor penyebab terjadinya gerakan tanah di lokasi tersebut adalah sebagai berikut: Kemiringan lereng yang terjal mengakibatkan tanah mudah bergerak, struktur geologi berupa patahan turun dilokasi gerakan tanah; jenis bantuan berupa lava/breksi yang bersisipan bantu lempung dan batu pasir; sifat tanah pelapukan bersifat poros/sarang, kurang kompak, jenuh air; system drainase permukaan yang kurang baik sehingga seluruh air baik air hujan maupun air limbah rumah tangga tidak terserap optimal; curah hujan yang tinggi dan 
berdurasi lama yang turun sebelum dan saat terjadinya gerakan tanah memicu terjadinya gerakan tanah.

\section{Permasalahan yang Harus Diselesaikan}

Permasalahan yang harus diselesaikan dengan pengabdian masyarakat ini adalah sebagai berikut:

1. Penduduk masih belum mengetahui tindakan yang harus dilakukan jika sewaktu-waktu terjadi bencana longsor .

2. Penduduk belum memanfaatkan lahanya secara baik, sehingga akan berpotensi longsor.

Permasalahan tersebut tentunya menjadi tantangan yang harus diselesaikan, sehingga diharapkan akan terjadi perubahan pengetahuan penduduk untuk lebih menyadari situasi yang dialami sehingga terjadi perubahan perilaku dalam memanfaatkan seluruh potensi yang ada di wilayahnya. Beberapa hal yang diharapkan berubah diantaranya adalah:

1. Penduduk memahami tindakan yang harus dilakukan jika terjadi bencana sekaligus mengetahui jalur evakuasi yang akan digunakan untuk menyelamatkan diri.

2. Penduduk dapat memanfaatkan lahan dengan baik, seperti melakukan penghijauan pada lahan-lahan kosong terutama pada lereng-lereng gunung, tidak melakukan penebangan pohon-pohon besar yang menjadi penahan air hujan, mempertimbangkan kemiringan maupun retakan dalam membangun rumah tinggal, membuat sistem drainase yang efektif sehingga tidak merubah struktur tanah di sekitar lokasi tempat tinggal.

\section{METODE PELAKSANAAN}

Metode yang digunakan untuk mengatasi persoalan mitra dalam kegiatan pengabdian masyarakat ini adalah dengan beberapa tahapan kegiatan yang saling terkait. Di tahap awal, dilakukan survei pemahaman penduduk terkait dengan potensi bencana di wilayahnya. Hal-hal yang diungkap antara lain adalah: 1. Identitas warga; 2 . pengalaman warga saat bencana terjadi; 3. Pemahaman warga terhadap bencana; 4. Tindakan yang dilakukan warga saat bencana terjadi; 5 . Serta upaya yang dilakukan oleh warga saat terjadi bencana. Di tahap kedua, penyusunan hasil pemetaan pemahaman. Hal ini dilakukan untuk memperoleh gambaran secara utuh bagaimana tingkat pemahaman warga terkait bencana yang dihadapi. Dengan mengetahui tingkatan pemahaman ini, intervensi yang dibuat bias lebih tepat. Tahap ke tiga, penyusunan modul intervensi pemahaman warga tentang wilayah bencana yang dihadapi. Modul ini akan mengkombinasikan antara penyampaian materi melalui ceramah, diskusi langsung dengan warga sekaligus malakukan simulasi upaya penyelamatan diri apabila terjadi bencana. Di tahap ke empat, akan dibuatkan peta jalur evakuasi berikut dengan tanda-tanda atau penunjuk arah di lokasi untuk mempermudah warga menuju tititk penyelamatan diri.

Setelah menyepakati tahapan yang harus dilakukan, selanjutnya membuat rencana kegiatan berikut dengan indikator keberhasilan yang menjadi target. Berikut ini merupakan table untuk menjelaskan rencana kegiatan yang akan dilakukan.

Tabel 1 Rencana Kegiatan

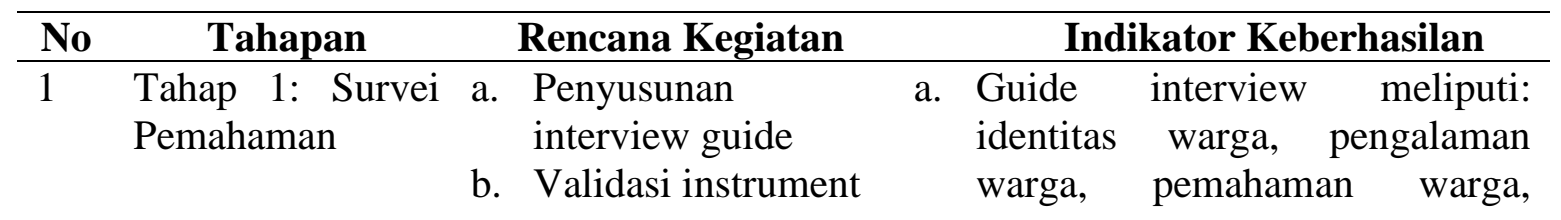




\begin{tabular}{|c|c|c|c|}
\hline No & Tahapan & Rencana Kegiatan & Indikator Keberhasilan \\
\hline & & $\begin{array}{l}\text { c. Pemetaan jumlah } \\
\text { warga berpotensi } \\
\text { terdampak } \\
\text { d. Pengambilan data }\end{array}$ & $\begin{array}{l}\text { tindakan saat bencana dan upaya } \\
\text { yang dilakukan saat bencana } \\
\text { terjadi } \\
\text { b. Data jumlah penduduk serta } \\
\text { sebaran penduduk di lokasi }\end{array}$ \\
\hline & $\begin{array}{l}\text { Tahap 2: } \\
\text { Penyusunan hasil } \\
\text { pemetaan } \\
\text { pemahaman }\end{array}$ & $\begin{array}{l}\text { a. Penyusunan } \\
\text { verbatim hasil } \\
\text { interview } \\
\text { b. Penyusunan laporan } \\
\text { hasil Survei } \\
\text { c. Penggolongan } \\
\text { pemahaman warga }\end{array}$ & $\begin{array}{l}\text { a. Laporan hasil survei dilakukan } \\
\text { secara menyeluruh mulai dari } \\
\text { pengalaman, pemahaman, } \\
\text { tindakan saat bencana hingga } \\
\text { upaya yang dilakukan saat } \\
\text { bencana terjadi } \\
\text { b. Penggolongan pemahaman } \\
\text { warga terkait bencana yang } \\
\text { dialami }\end{array}$ \\
\hline & $\begin{array}{l}\text { Tahap 3: } \\
\text { Penyusunan } \\
\text { modul intervensi } \\
\text { pemahaman }\end{array}$ & $\begin{array}{lr}\text { a. } & \text { Mengumpulkan } \\
\text { materi } & \\
\text { b. } & \text { Menyusun materi } \\
\text { untuk } & \text { tiap-tiap } \\
\text { metode } & \text { yang } \\
\text { digunakan } & \\
\text { c. } & \text { Mendata peserta } \\
& \text { yang akan dilibatkan }\end{array}$ & $\begin{array}{l}\text { a. Modul intervensi memuat } \\
\text { metode-metode yang bervariasi }\end{array}$ \\
\hline & $\begin{array}{l}\text { Tahap 4: Peta } \\
\text { jalur evakuasi }\end{array}$ & $\begin{array}{lr}\text { a. } & \text { Melakukan survey } \\
& \text { lokasi untuk jalur } \\
& \text { evakuasi } \\
\text { b. } & \text { Melakukan simulasi } \\
& \text { efektifitas jalur } \\
& \text { evakuasi } \\
\text { c. } & \text { Menentukan lokasi } \\
& \text { titik kumpul } \\
\text { d. } & \begin{array}{l}\text { Membuat data peta } \\
\text { jalur evakuasi }\end{array} \\
\text { e. } & \begin{array}{l}\text { Membuat dan } \\
\text { memasang tanda }\end{array} \\
& \text { untuk jalur evakuasi }\end{array}$ & $\begin{array}{l}\text { a. Peta jalur dibuat dengan efektif } \\
\text { b. Titik kumpul dapat diakses } \\
\text { dengan aman } \\
\text { c. Simbol atau tanda yang terpasang } \\
\text { dapat dilihat dengan jelas }\end{array}$ \\
\hline
\end{tabular}

Secara lebih sederhana, berikut ini merupakan diagram alir yang menunjukan setiap tahap pelaksanaan kegiatan. 


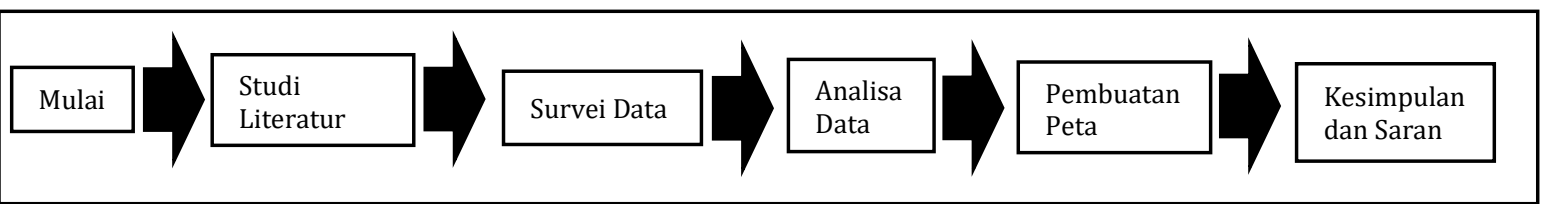

Gambar 1. Diagram Alir dari Tahap Pelaksanaan Kegiatan

\section{HASIL dan PEMBAHASAN}

Kegiatan pemetaan pemahaman warga tentang bencana telah dilakukan di Dusun Gembes RT 19 Desa Slahung Kabupaten ponorogo. Di dusun tersebut memiliki populasi sebesar lima puluh satu (51) keluarga namun demikian di dalam kegiatan ini hanya melibatkan 35 (tiga puluh lima) keluarga sebagai sampel yang akan diambil datanya. Pemilihan jumlah sampel ini mempertimbangkan keterjangkauan rumah warga dan pertimbangan efektifitas waktu. Selama empat (4) hari melakukan survey, diperoleh data-data sebagai berikut:

1. Pengalaman masyarakat dengan bencana

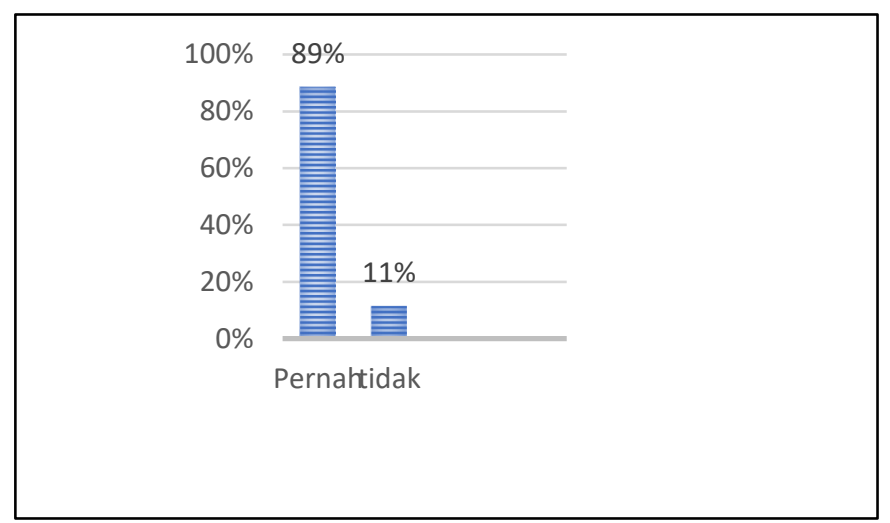

Gambar 2. Pengalaman Masyarakat dengan Bencana

2. Bencana yang pernah terjadi

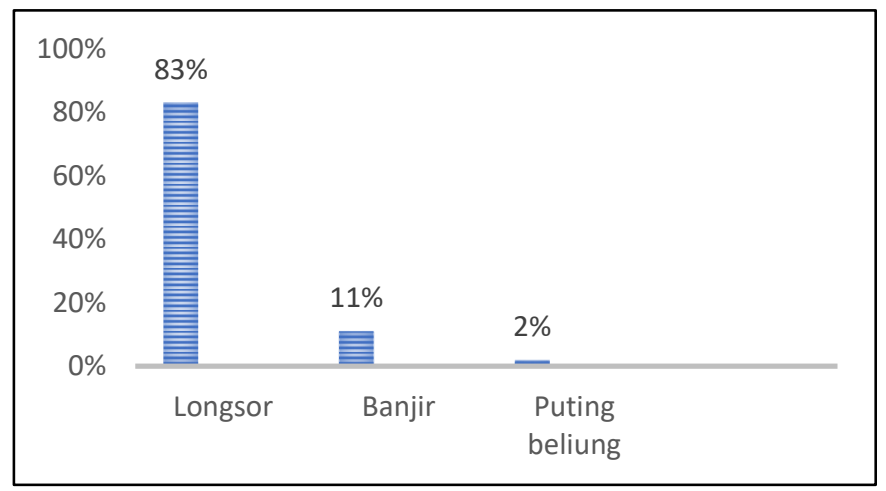

Gambar 3. Bencana yang Pernah Terjadi 
3. Waktu terjadinya bencana

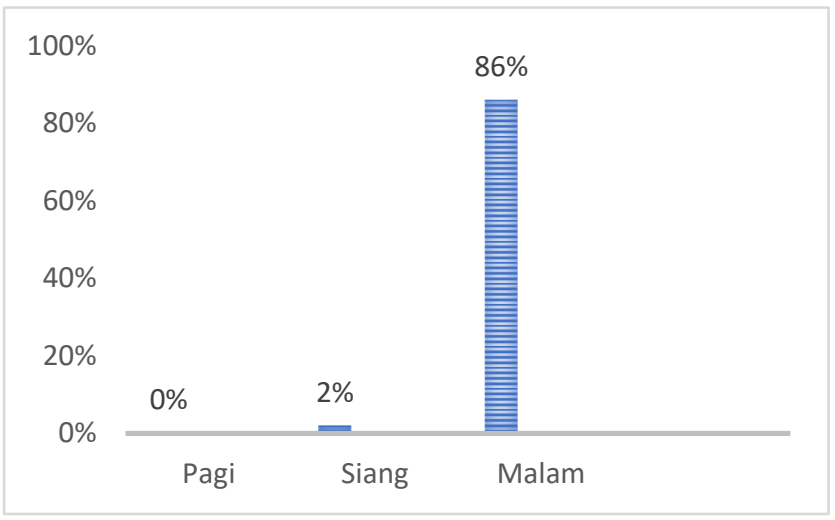

Gambar 4. Waktu Terjadinya Bencana

Grafik diatas menggambarkan pengalaman masyarakat saat terjadi bencana, sebanyak 89\% warga pernah merasakan bencana yang terjadi. Sebagian besar jenis bencana yang terjadi dan dialami oleh warga adalah longsor. Longsor ini terjadi dalam skala kecil maupun dalam skala besar. Selain itu ada sebanyak $11 \%$ bencana banjir yang pernah dialami oleh warga dan bencana putting beliung sebanyak $2 \%$. Sebagian besar bencana terjadi pada malam hari dan selebihnya terjadi siang hari.

Selanjutnya, hasil survey juga mengungkap pengetahuan warga yang tinggal di lokasi bencana. Berikut merupakan grafik yang menunjukan pengetahuan dan perasaan warga.

1. Perasaan tinggal di lokasi

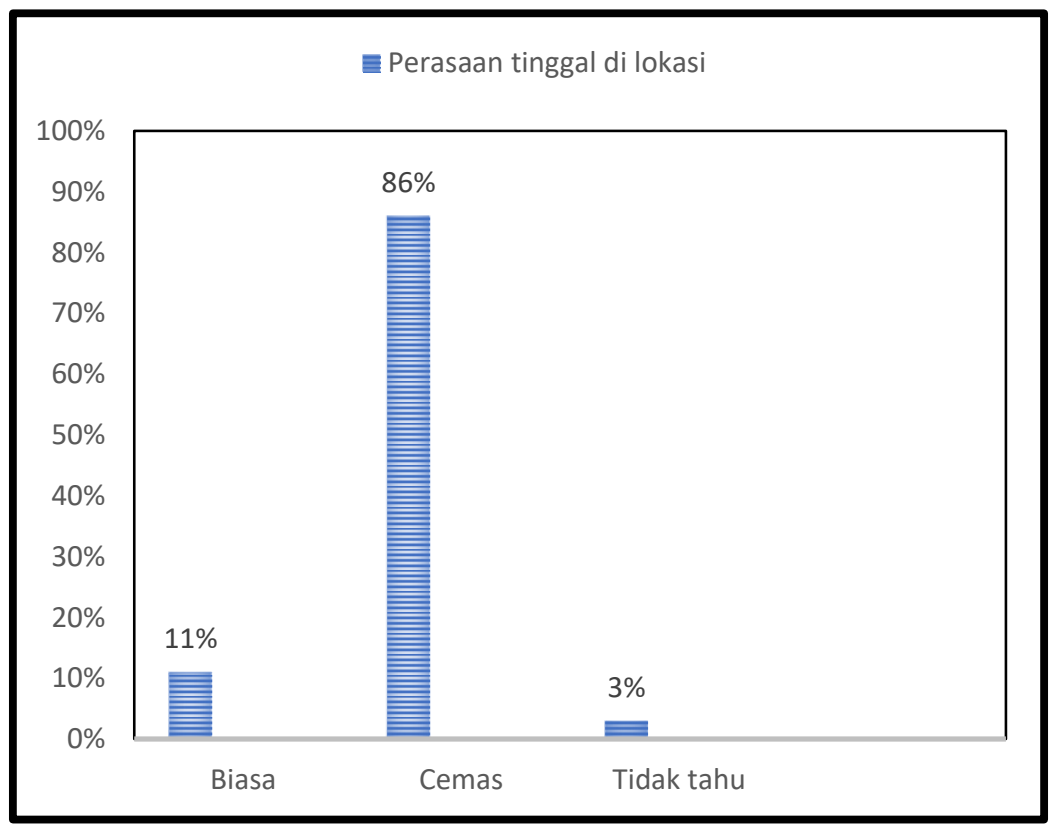

Gambar 5. Grafik Perasaan Tinggal Dilokasi 
2. Pertimbangan membangun rumah

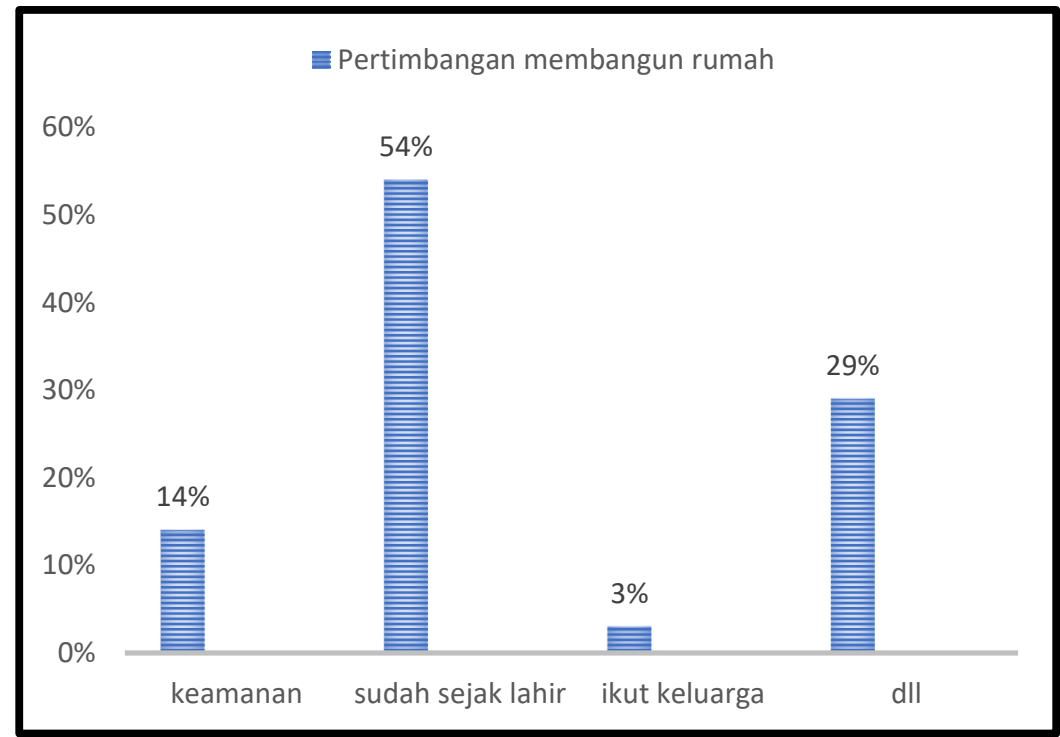

Gambar 6. Grafik Pertimbangan Membangun Rumah

3. Kerugian yang pernah dialami

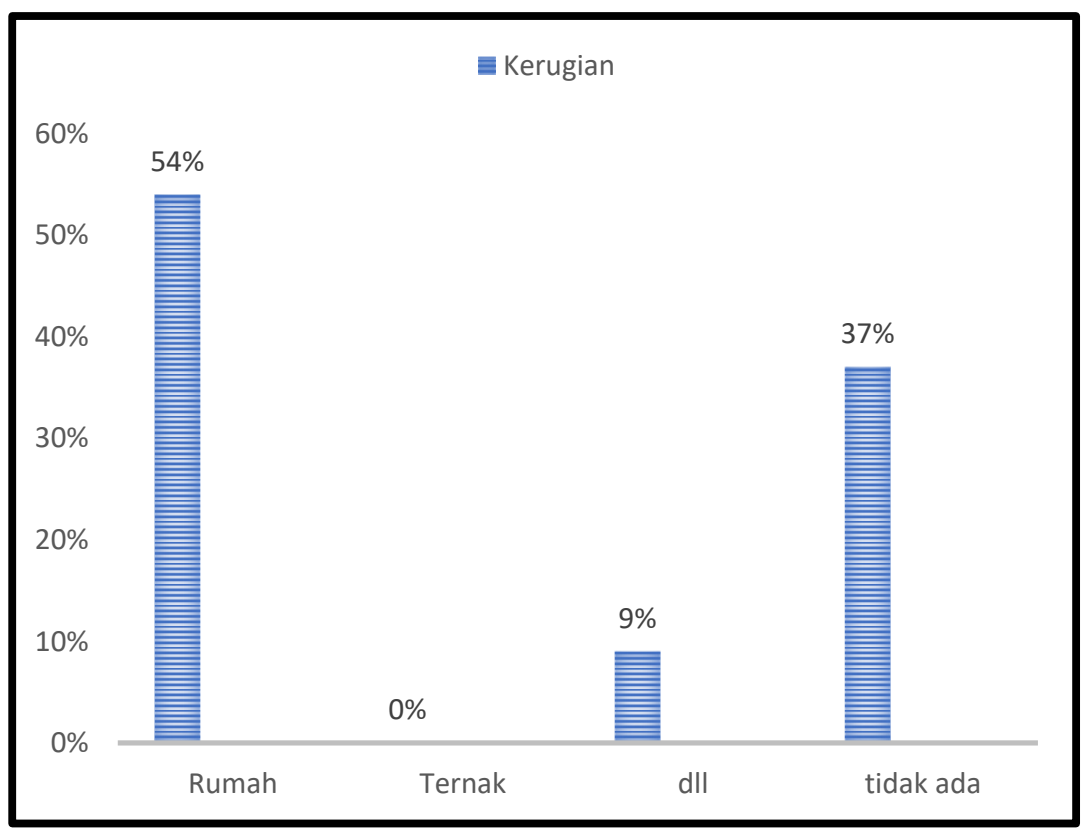

Gambar 7. Grafik Kerugian yang Pernah Dialami 


\section{Fenomena alam}

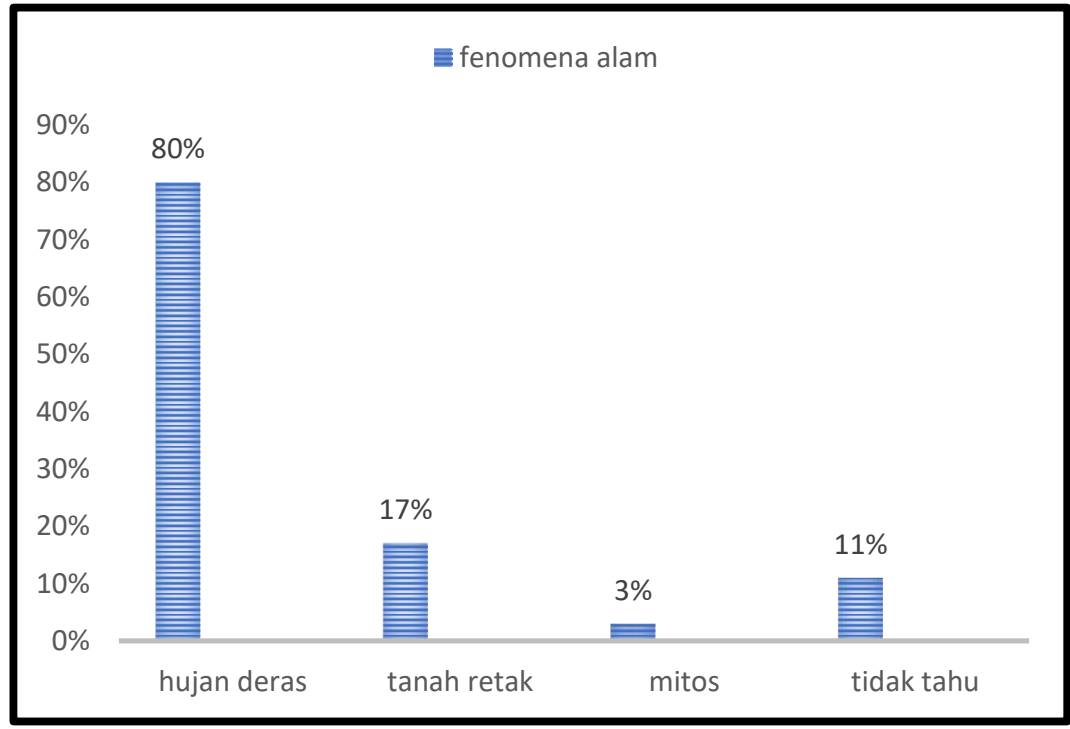

Gambar 8. Grafik Fenomena Alam

Dalam grafik diatas merupakan hasil analisis dari indikator yang kedua yaitu mengenai pengetahuan tentang bencana, dalam indikator perasaan atau suasana hati masyarakat, mayoritas masyarakat cemas, takut dan was was hal ini dtunjukkan dengan tingkat persentase yang mencapai $86 \%$ dan tidak cemas atau normal di angka $11 \%$ itu artinya potensi masyarakat mengalami ketakutan dan berujung traumatik akan sangat besar.

Dalam indikator berikutnya yaitu mengenai pertimbangan membangun rumah, masyarakat dilokasi ini mayoritas adalah sejak lahir atau rumah warisan yang didiami oleh masyarakat secara turun temurun. Hal ini ditunjukkan oleh tinggkat persesentasenya yang mencapai 54\%. Disamping itu ada juga masyarakat yang ikut istri, dan masyarakat yang mempertimbangkan segi keamanan pun sebanyak 14\%. Maka dapat disimpulkan bahwa masyarakat yang mendiami lokasi ini tidak punya pilihan lain selain tinggal dilokasi ini dikarenakan memang adanya keterbatasan biaya dan enggan meningglkan pekerjaannya.

Dalam indikator berikutnya mengenai kerugian yang diderita masyarakat yang terdampak bencana longsor sebagian besar adalah materil yaitu rumah dengan tingkat persentase $54 \%$ selain itu adapula tanaman berupa cengkeh dll sebesar $9 \%$ dan sebanyak 37\% tidak mengalami kerugian apapun.

Dalam indikator berikutnya mengenai Tanda-tanda alam yang diyakini sebagai tanda datangnya bencana khusunya longsor. Dalam hal ini, mayoritas masyarakat mengetahui dan paham dengan tanda-tanda akan terjadi bencana, tanda tanda yang diyakini meliputi hujan deras yang memperoleh persentase sebanyak $80 \%$ yang merupakan tana-tanda utama, kemudian ada Tanah retak sebagi tanda-tanda kedua dengan pesentase sebesar $17 \%$, ada beberapa masyarakat yang meyakini dengan mitos yaitu keluarnya ular besar dari sarangnya yang diyakini sebagai tanda akan datangnya bencana dengan persentase 3\% dan yang belum tahu tentang tanda-tanda alam sebesar 13\%. Artinya dalam hal ini mayoritas masyarakat sudah paham apa yang merupakan tanda-tanda alam sehingga masyarakat dapat mengantisipasi dan memeprsiapkan diri jika bencana itu terjadi. 
Selanjutnya, di bawah ini diuraikan grafik yang menunjukan gambaran tindakan yang dilakukan oleh warga serta upaya yang dilakukan untuk mencegah munculnya bencana.

1. Tindakan saat terjadinya bencana

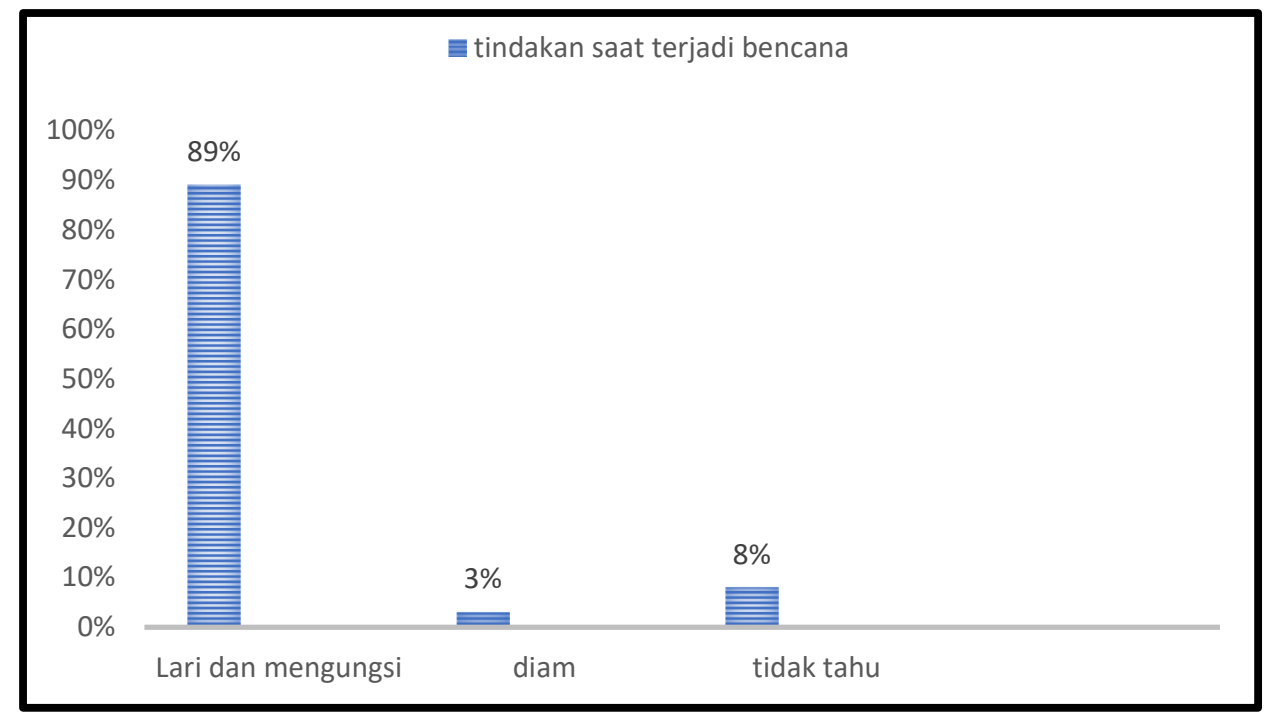

Gambar 9. Grafik Tindakan saat Terjadinya Bencana

2. Pengetahuan warga tentang lokasi aman

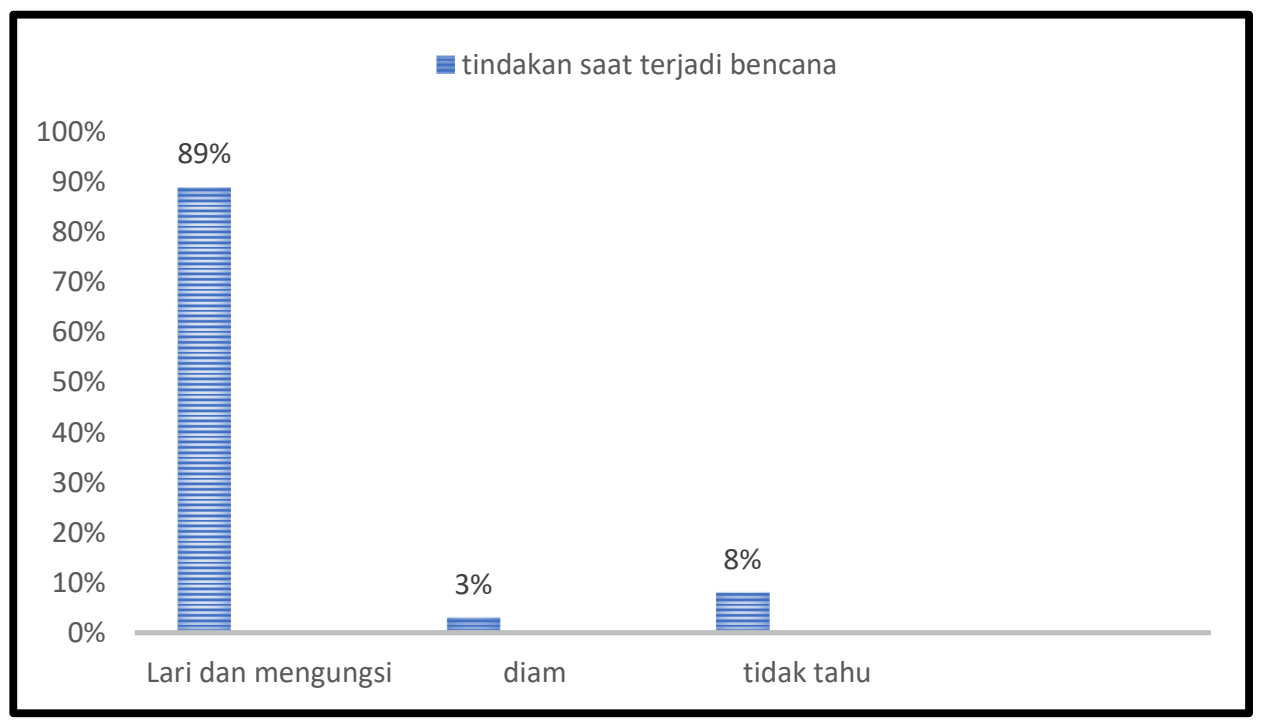

Gambar 10. Grafik Pengetahuan Warga Tentang Lokasi Aman 
3. Upaya pencegahan terhadap bencana

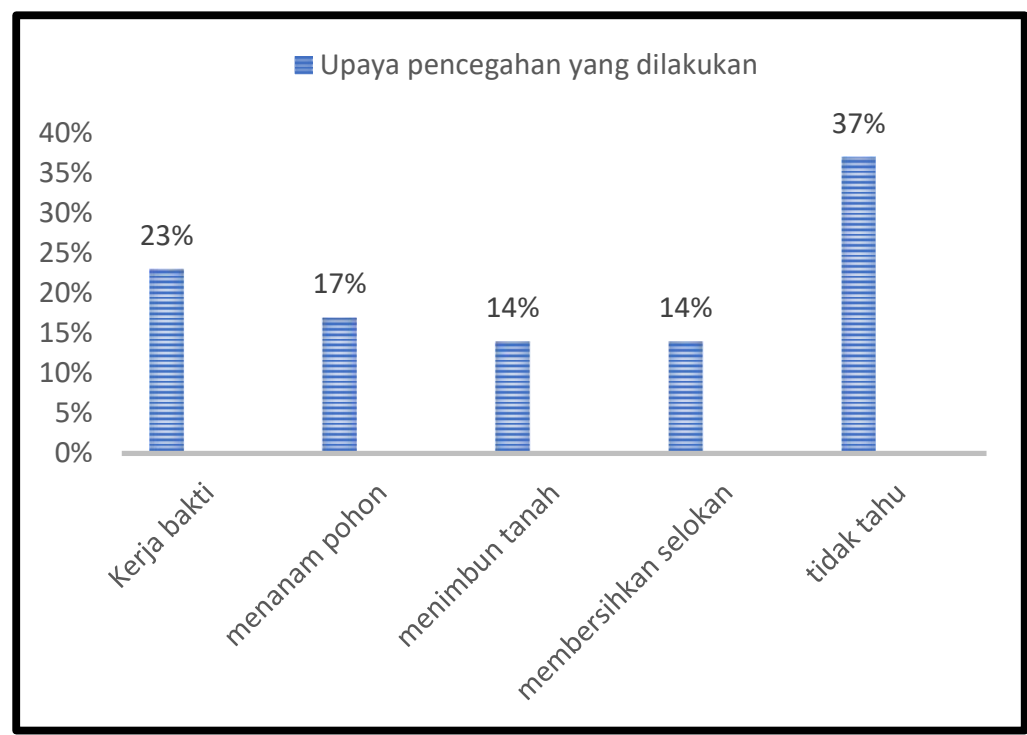

Gambar 11 Upaya Pencegahan Terhadap Bencana

4. Ritual khusus yang dilakukan warga mencegah bencana

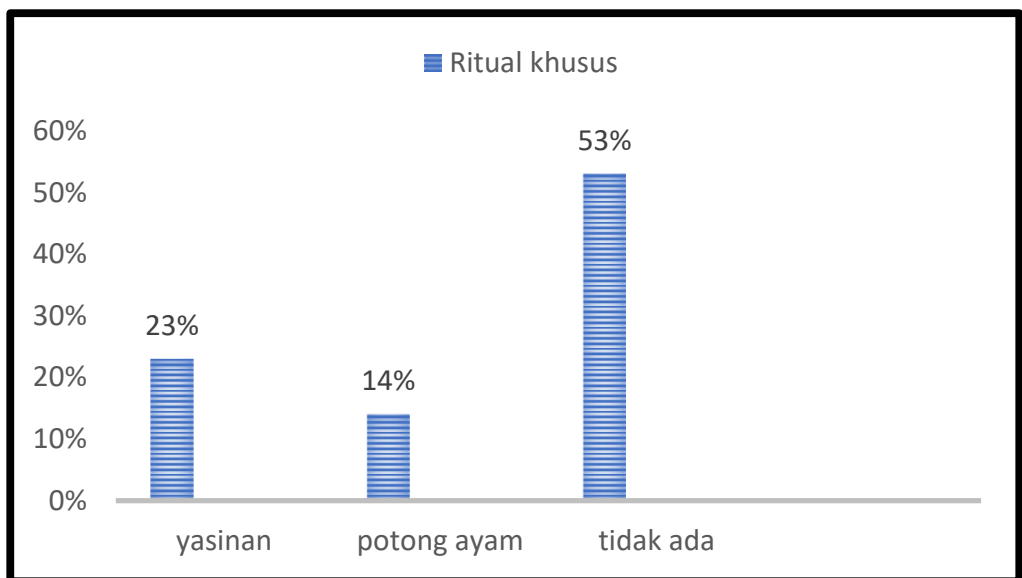

Gambar 12 Ritual Khusus yang Dilakukan Warga Mencegah Bencana

Grafik diatas adalah hasil analis pada indikator mengenai tindakan yang dilakukan masyarakat saat terjadi bencana. Dalam indikator pertama yaitu tindakan yang dilakukan saat terjadi bencana, mayoritas masyarakat lari dan mengungsi, hal ini ditunjukkan dengan persentasenya yang mencapai $89 \%$ dan hanya 3\% yang memilih diam tidak melakukan apaapa. Apabila dikaitkan dengan pengetahuan tentang lokasi aman, mayoritas masyarakat sudah paham tentang lokasi yang dianggap aman saat terjadi bencana yaitu masyarakat pergi ke tempat pengungsian yang sudah ditetapkan oleh BPBD yaitu di tempat pengungsian di SDN 2 Snepo dengan jumlah persentase $71 \%$ dan ada juga yang pergi ke rumah saudaranya yang dianggap aman dengan persentase $11 \%$ dan yang menjawab tidak tahu sebesar $18 \%$. 
Dalam indikator yang ketiga yaitu mengenai upaya masyarakat untuk pencegahan atau meminimalisir kerugian saat terjadi bencana. Mayotitas masyarakat belum memahami terkait upaya pencegahan ini, hal ini dapat terlihat bagaimana jumlah persentase masyarakat yang tidak tahu mencapai 37\%, sebagian lagi ada yang kerja bakti dengan persentase $23 \%$ menanam pohon sebesar $17 \%$, menimbun tanah $14 \%$ dan membersihkan selokan sebesar $14 \%$. Dapat disimpulkan pemahaman masyarakat kurang dalam tindakan upaya pencegahan dan memenimalisir kerugian akibat bencana.

Hasil analisis pada indikator berikutnya yaitu ritual yang biasa dilakukan oleh masyarakat untuk mencegah terjadinya bencana. Dalam hal ini masyarakat di lokasi ini masih berpegang teguh dengan budaya dan kearifan lokal dan basis spiritual. Hal ini di tunjukkan dengan masyarakat melakukan syukuran berupa yasinan degan persentase mencapai $23 \%$ dan potong ayam atau kenduri $14 \%$ sedangkan sisa nya menjawab tidak tahu. Sedangkan dalam indikator terakhir yaitu tentang harapan masyarakat terhadap pemerintah seluruh masyarakat yang ada di daerah tersebut menginginkan peran pemerintah yang lebih besar untuk mengupayakan kesejahteraan masyarakat diwilayah ini melalui tindakan relokasi dan pemberiaan lahan produktif disertai pembangunan rumah layak huni.

\section{KESIMPULAN}

Kesimpulan dari kegiatan pengabdian masyarakat yaitu :

1. Program ini menghasilkan modul intervensi pemahaman yang memuat metode-metode yang bervariasi.

2. Dari aktifitas simulasi penanganan bencana diperoleh hasil peningkatan kemampuan masyarakat memahami efektifitas jalur evakuasi, mengetahui titik kumpul yang telah disediakan sehingga dapat mempermudah jalannya evakuasi.

3. Tersusun peta jalur dengan lebih efektif yang dapat mempermudah dan mengamankan akses menuju titik kumpul.

\section{DAFTAR PUSTAKA}

Faisal Akhmadi dkk.2017. "Pemetaan Jalur Evakuasi Dan Pengungsian Di Kecamatan BatiBati Kabupaten Tanah Laut".Jurnal Pendidikan Geografi, ppjp.ulm.

Gede Sarya.2014."Intensitas Curah Hujan Memicu Tanah Longsor Dangkal di Wonodadikulon". Jurnal Pengabdian Masyarakat.LPPM Untag Surabaya.

Hary Christady Hardiyatmo.1992."Mekanika Tanah I".Gramedia Pustaka Utama, Jakarta.

Joseph E. Bowles.1991."Sifat-Sifat Fisis dan Geoteknis Tanah". Erlangga.Jakarata.

M. Wijanarko.2016."Pendidikan Bencana Dan Respon Psikososial Pada Guru Di Desa Tempur. Kabupaten Jepara”. Jurnal Psikologi Perspektual.

Nurfaida.2015."Penggunaan Sig Untuk Pemetaan Jalur Evakuasi Bencana Tsunami Di Desa Tonggolobibi Kecamatan Sojol Kabupaten Donggala".E-Journal Geo-Tadulako UNTAD.

Rahman Zarkasyi, Amni. 2015. "kajian mitigasi bencana tanah longsor di Kabupaten Banjarnegara". jurnal manajemen dan kebijakan publik, Universitas Diponegoro.

Santoso, Heri. 2019. "Analisis Tanah Lempung Ekspansif Pamekasan Menggunakan Bahan Stabilisasi Abu Jerami”. tugas akhir. program studi teknik sipil, fakultas teknik, universitas 17 agustus 1945 surabaya. 